\title{
The prognosis of the perforated acute duodenal ulcer
}

\author{
PAUL CASSELL
}

From the Royal Berkshire Hospital, Reading

The use of the terms 'acute' and 'chronic' when describing perforated duodenal ulcers has sometimes produced confusion. It is obviously incorrect to speak of an 'acute perforation' because all perforations are acute although some may be small and therefore leak slowly. On the other hand, it is established that both acute and chronic ulcers perforate, although it may appear to be of academic interest only to differentiate between them. However, Lowdon (1952) has shown that the duration of dyspepsia correlates with the histological findings, for in patients with a history of less than one month, $80 \%$ of the ulcers showed no signs of chronicity. Most authorities who have classified their patients in this way have concluded that patients with an acute ulcer fare better than those whose lesion is chronic (Illingworth, Scott, and Jamieson, 1946; Gilmour, 1953; Taylor and Warren, 1956). Indeed, Taylor has claimed that the mortality, complications, and disability following perforation are almost completely confined to the chronic ulcer group, and he therefore pays careful attention to the patient's previous history, and treats all those with perforation of an acute ulcer conservatively.

However, a report on a recent series of perforated duodenal ulcers suggests that the prognosis of patients with an acute lesion is worse than for those with chronic ulcers (Hofkin, 1966). The series only comprised 57 patients of whom 13 had an acute ulcer. Eleven of them had a simple closure and all but one of these subsequently suffered further symptoms, eight coming to definitive surgery. The two other 'acute' patients had a definitive procedure initially and both of them required a further operation for recurrent ulceration.

It seemed to us to be of more than passing interest to discover which of these two contrasting experiences was appropriate to our surgical practice, because whilst Taylor urges non-operative conservative treatment, Hofkin recommends immediate definitive surgery in the management of the acute duodenal perforation.

\section{DESCRIPTION OF PATIENTS}

The records of all patients presenting at the Royal
Berkshire Hospital with a perforated duodenal ulcer between January 1950 and December 1959 were examined and a report of the overall findings is made elsewhere (Cassell, 1969). During this period, 330 sustained 335 perforations (five patients had a second perforation and were readmitted within the duration of the survey). A careful study of the histories of patients treated operatively was made to establish the duration of pre-perforation dyspepsia. In common with other reports, an acute ulcer was taken to be one perforating in a patient with dyspepsia for less than three months (Illingworth et al, 1946; Taylor and Warren, 1956; Hofkin, 1966). In most cases a clear history was obtained from the patient either on admission or when a decision about further treatment was being considered postoperatively. In some instances the history was not clear from the records and then when the patient was contacted at follow up, he was specifically questioned. Unfortunately, 13 patients with incomplete records had died, and they were therefore excluded from the analysis.

The report presents the diagnosis and follow up of 294 patients who, during the 10-year period, sustained 299 perforations (Table I). Seventy-three patients $(24.8 \%)$ had acute lesions, and one of them sustained a second perforation during the 10-year period under survey. Chronic ulcers perforated in 221 patients, and four of them re-perforated before 1960. This finding falls within the range of similar investigations, Hofkin found an incidence of $23 \%$ and Taylor of $25 \%$ (this latter figure includes gastric as well as duodenal perforations).

TABLE I

\begin{tabular}{lcccc}
\multicolumn{5}{c}{ ANALYSIS OF PATIENTS AND OPERATIVE } \\
MORTALITY RATES \\
$\begin{array}{l}\text { No. of } \\
\text { Patients }\end{array}$ & $\begin{array}{l}\text { No. of } \\
\text { Perforations }\end{array}$ & $\begin{array}{l}\text { No. of. } \\
\text { Operative } \\
\text { Deaths }\end{array}$ & $\begin{array}{l}\text { Operative } \\
\text { Mortality } \\
\text { Rate }(\%)\end{array}$ \\
\hline $\begin{array}{l}\text { Acute } \\
\text { Chronic }\end{array}$ & 221 & 74 & 4 & $\begin{array}{l}5.4 \\
5.5\end{array}$
\end{tabular}

AGE The number of patients within each decade is shown in Figure 1. A very steep rise in the number of patients with perforated chronic ulcer over the 572 


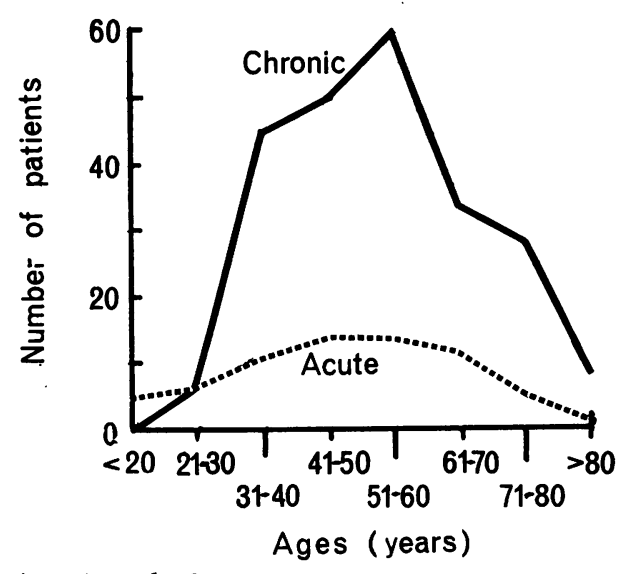

FIG. 1. Annual admissions.

age of $\mathbf{3 0}$ is observed. The 'acute perforators' whilst commoner over this age also do not show such a marked increase. Once again these findings are comparable to those of the other series already referred to in which the average age of patients with perforating acute ulcers tended to be younger than those with chronic lesions.

SEX The male to female ratio is the same for acute and chronic ulcers, being 5.75 to 1 and 6.15 to 1 respectively (Table II).

TABLE II

SEX INCIDENCE OF PATIENTS

\begin{tabular}{lll} 
& Acute & Chronic \\
\hline Male & 62 & 190 \\
Female & 11 & 31 \\
Ratio, male to female & 5.75 to 1 & $6 \cdot 15$ to 1
\end{tabular}

MANAGEMENT AND FOLLOW UP

ACUTE ULCER Only two patients in this group had definitive surgery initially in the form of partial gastrectomy. The other 71 patients had simple closure of the perforation, gastrojejunostomy being added in one case, and $14(20 \%)$ of them eventually came to definitive surgery later. Neither the patient treated by simple closure with gastrojejunostomy, nor the two patients with partial gastrectomy, had recurrent ulceration.

CHRONIC ULCER One hundred and fifty-four patients had simple closure only and of these $67(43.5 \%)$ required a further operation. Two out of 17 patients $(11.8 \%)$ with gastrojejunostomy also had recurrent symptoms warranting definitive surgical treatment. Fifty patients received immediate partial gastrectomy and two (4\%), who had a Billroth I operation, had further symptoms and a Polya conversion.

Those patients with acute ulcers who are managed by simple closure only come to further surgery less often than those with chronic ulcers, the reoperation rates for the two groups being $20 \%$ and $43.5 \%$ respectively. The number of patients with acute dyspepsia, managed by other surgical procedures, is too small for comparison. Nevertheless, on the basis of the findings amongst those patients receiving simple closure only, it is clear that the prognosis for those with perforation of an acute ulcer is significantly better (Table III).

INDICATIONS FOR FURTHER SURGERY The factors leading to further operation are outlined in Table IV. It will be noted that when those patients who were referred for elective operation on account of their pre-perforation history are excluded, the indications for further surgery within the acute and chronic ulcer groups were generally similar but with one exception. Patients whose acute ulcers perforate appear from our series to have a doubled risk of subsequent haemorrhage from the lesion.

\section{MORTALITY RATE}

Some surgeons have reported no fatality from perforated acute ulcer in their series (Gilmour, 1953; Taylor and Warren, 1956). Unfortunately this has not been our experience. There were four deaths

TABLE III

MANAGEMENT AND FOLLOW UP

\begin{tabular}{|c|c|c|c|c|c|c|}
\hline \\
\hline & \multicolumn{2}{|c|}{ Simple Closure only } & \multicolumn{2}{|c|}{$\begin{array}{l}\text { Simple Closure and } \\
\text { Gastrojejunostomy }\end{array}$} & \multicolumn{2}{|c|}{ Partial Gastrectomy } \\
\hline & $\begin{array}{l}\text { Number of } \\
\text { Patients }\end{array}$ & $\begin{array}{l}\text { Number } \\
\text { Requiring } \\
\text { Further } \\
\text { Surgery }\end{array}$ & $\begin{array}{l}\text { Number of } \\
\text { Patients }\end{array}$ & $\begin{array}{l}\text { Number } \\
\text { Requiring } \\
\text { Further } \\
\text { Surgery }\end{array}$ & $\begin{array}{l}\text { Number of } \\
\text { Patients }\end{array}$ & $\begin{array}{l}\text { Number } \\
\text { Requiring } \\
\text { Further } \\
\text { Surgery }\end{array}$ \\
\hline $\begin{array}{l}\text { Acute } \\
\text { (73 patients) } \\
\text { Chronic } \\
\text { (221 patients) }\end{array}$ & $\begin{array}{r}70 \\
154\end{array}$ & $\begin{array}{l}14 \\
(20 \%) \\
67 \\
(43.5 \%)\end{array}$ & $\begin{array}{r}1 \\
17\end{array}$ & $\begin{array}{l}0 \\
(-) \\
2 \\
(11.8 \%)\end{array}$ & $\begin{array}{r}2 \\
50\end{array}$ & $\begin{array}{l}0 \\
(-) \\
2 \\
(4 \%)\end{array}$ \\
\hline
\end{tabular}


TABLE IV

INDICATIONS FOR DEFINITIVE SURGERY DURING THE FOLLOW-UP PERIOD

\begin{tabular}{|c|c|c|c|c|c|c|c|}
\hline & $\begin{array}{l}\text { Total } \\
\text { Number of } \\
\text { Patients }\end{array}$ & $\begin{array}{l}\text { Number } \\
\text { Coming to } \\
\text { Further } \\
\text { Surgery }\end{array}$ & $\begin{array}{l}\text { Elective } \\
\text { Operation }\end{array}$ & $\begin{array}{l}\text { Recurrent } \\
\text { Symptoms }\end{array}$ & $\begin{array}{l}\text { Further } \\
\text { Perforation }\end{array}$ & $\begin{array}{l}\text { Pyloric } \\
\text { Stenosis }\end{array}$ & Haemorrhage \\
\hline Acute & 73 & 14 & Nil & $\begin{array}{c}7 \\
(50 \%)\end{array}$ & $\begin{array}{l}2 \\
(14 \cdot 3 \%)\end{array}$ & $\stackrel{1}{(7 \cdot 10 \%)}$ & $\begin{array}{c}4 \\
(28.6 \%)\end{array}$ \\
\hline Chronic & 221 & 71 & $\begin{array}{l}6 \\
(9 \cdot 4 \%)\end{array}$ & $\begin{array}{c}44 \\
(62 \%)\end{array}$ & $\begin{array}{c}7 \\
(9.85 \%)\end{array}$ & $\begin{array}{c}5 \\
(7.05 \%)\end{array}$ & $\begin{array}{c}9 \\
(12 \cdot 7 \%)\end{array}$ \\
\hline
\end{tabular}

following surgery in patients with acute ulceration. A man of 66 died with pericarditis and heart failure, another elderly man died with bronchopneumonia, and a third young patient died in delirium tremens. The fourth patient succumbed because of his serious preoperative condition, necropsy confirming the acute nature of the ulcer. These four deaths out of 73 patients represents a mortality rate of $5.5 \%$, compared with $5.4 \%$ for chronic ulcer sufferers (12 deaths in 221 patients).

\section{DISCUSSION}

Analysis of the patients presenting with perforated acute and chronic duodenal ulcers shows that within each group there is no significant sex difference, although the former tend to be of a younger average age.

The operative mortality in the two groups is similar and in this respect the findings do not agree with those of other reviewers who found the acute group to have a lower fatality rate. It is not the basic method of management which is responsible since, while Taylor and Warren (1956) adopted a policy of non-operative conservatism, all of Gilmour's patients (1953) were treated by simple closure. There are several factors which influence the successful outcome of treatment for a perforated peptic ulcer, and many of them are common to both acute and chronic ulcers. It is not clear why other reviewers should have found such a marked difference in operative mortality.

Taylor makes a case for the conservative management of acute ulcers both on the basis of this finding and of their lower complication rate. Certainly our experience confirms that acute ulcers require further surgery less than half as often as chroric ulcers. However, Taylor claims that most of the recurrences which do arise amongst patients with a perforated acute ulcer are attributable to the initial surgery perpetuating an ulcer which would have otherwise healed. His suggestion that acute ulcers should be managed conservatively obviously deserves further examination. It is clear that perforated acute ulcers tend to run a more benign course than chronic ulcers. If Taylor's claim that an important factor in their perpetuation is the trauma caused by simple closure, then in the face of its low mortality and morbidity, conservative treatment demands a more extensive trial.

\section{SUMMARY}

An analysis of 294 patients presenting with perforated duodenal ulcer and their subsequent management and follow up is reported. Those patients with only a brief dyspeptic history before perforation are shown to have an appreciably lower incidence of complications, although the operative mortality rate was no different from patients with chronic ulcers.

I wish to express my gratitude to the surgeons of the Royal Berkshire Hospital for allowing me access to their patients, and in particular to Mr Gordon Bohn for his advice and encouragement in the preparation of these papers.

\section{REFERENCES}

Cassell, P. G. (1969). Perforated duodenal ulcer at Reading, 1950 to 1959. Gut, 10, 454-459.

Gilmour, J. (1953). Prognosis and treatment in acute perforated peptic ulcer: a review of 206 cases. Lancet, 1, 870-873.

Hofkin, G. A. (1966). Course of patients with perforated duodenal ulcers. Amer. J. Surg., 111, 193-196.

Illingworth, C. F. W., Scott, L. D. W., and Jamieson, R. A. (1946) Progress after perforated peptic ulcer. Brit. med. J., 1, 787. 790.

Lowdon, A. G. R. (1952). The treatment of acute perforated peptic ulcer by primary partial gastrectomy. Lancet, 1, 1270-1274.

Stabins, S. J. (1953). The aftermath of perforated duodenal ulcer. Surgery, 34, 614-620.

Taylor, H., and Warren, R. P. (1956). Perforated acute and chronic peptic ulcer: conservative treatment. Lancet, 1, 397-399. 